
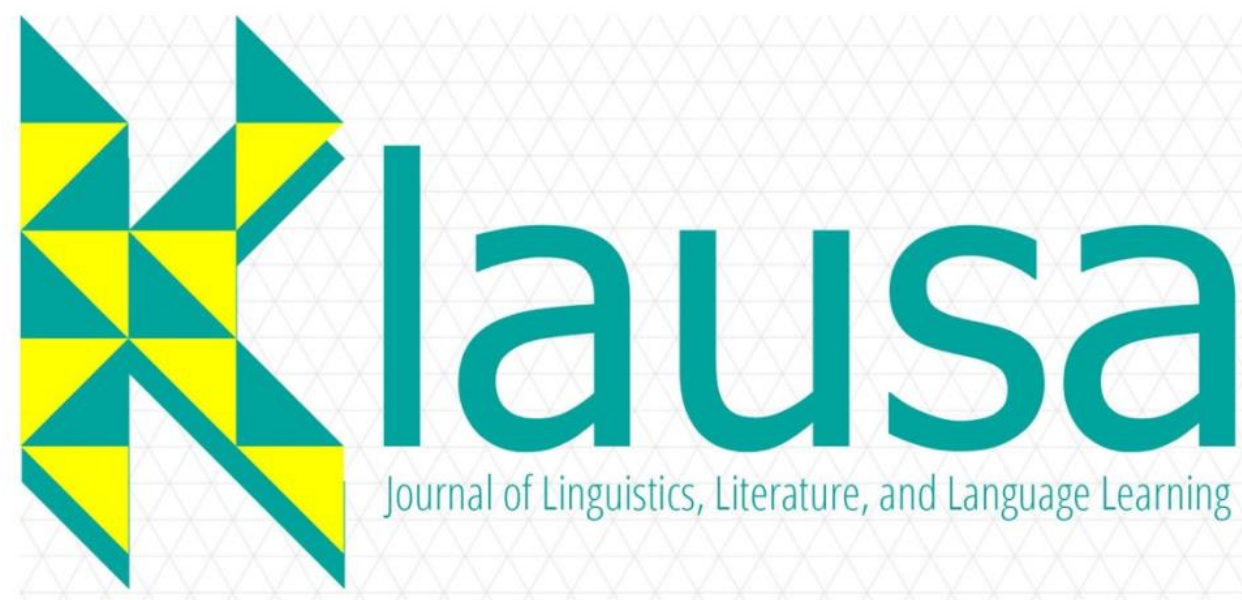

ISSN 2620-9527

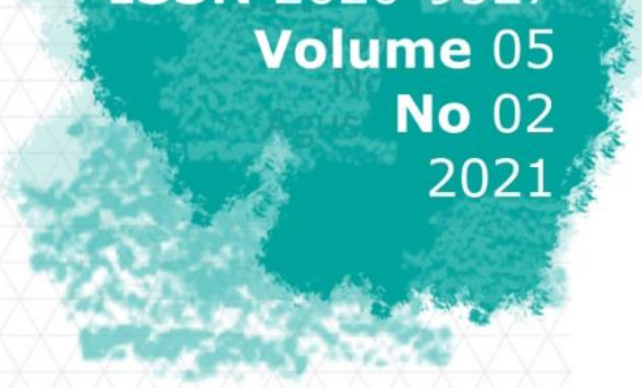

Journal of Linguistics, Literature, and Language Learning

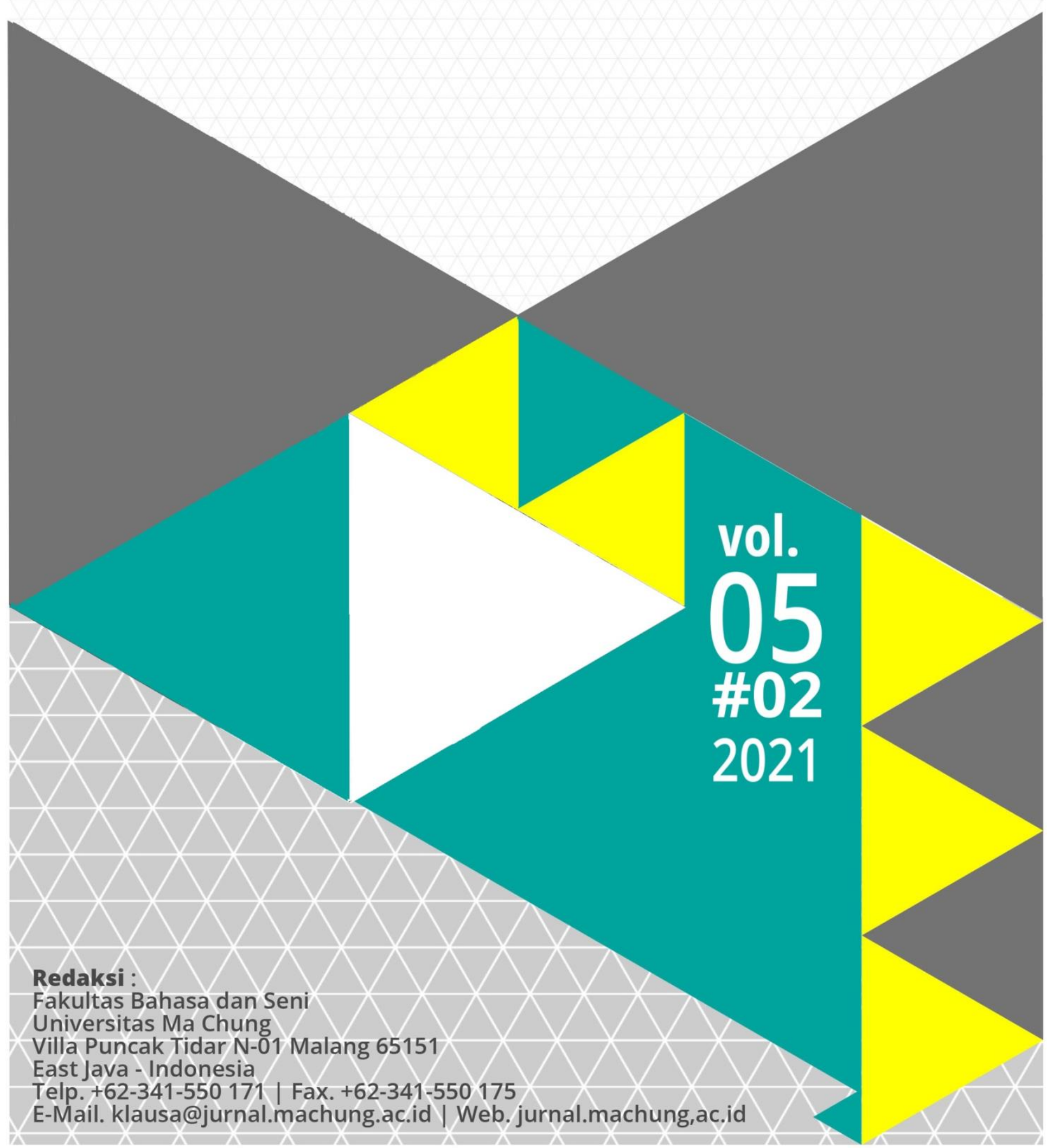


ISSN: $2301-4822(p)$

2620-9527 (e)

DOI:

\section{Kajian Linguistik, Pembelajaran}

Bahasa, dan Sastra

\section{Editorial Team}

Editor-in-Chief:Dr. Daniel Ginting

Journal Manager:Wawan Eko Yulianto, Ph.D.

Editors: Prof. Dr. Patrisius I. Djiwandono

Lilis Lestari Wilujeng, M.Hum.

Reviewers:F.X Dono Sunardi, M.A.

Dhatu Sitaresmi, MTCSOL.

Anggrah Diah Arlinda, MTCSOL.

Yohanna Nirmalasari, S.Pd., M.Pd.

Prof. A. Effendi Kadarisman, Ph.D.

Sisilia Halim, Ph.D.

Dr. Mundi Rahayu

Dr. Ross Wood

Dr. Leticia Araceli Salas Serrano

Publisher: Faculty of Language and Arts

Universitsas Ma Chung

Address: The Faculty of Language and Arts

$$
\begin{aligned}
& \text { Ma Chung University } \\
& \text { Villa Puncak Tidar N-01 (65151) } \\
& \text { Malang, East Java, Indonesia } \\
& \text { Email: jurnal.klausa@machung.ac.id }
\end{aligned}
$$

Frequency: Twice a year 


\section{CONTENTS}

FOREWORD

iii

SOLIDARITY IN THE TOURING NARRATIVE OF S.U.U.A.L (SCOOTER UIN ULUL ALBAB)

MALANG VESPA COMMUNITY: A CRITICAL DISCOURSE ANALYSIS APPROACH

Yunia Dewi Fathmawati ${ }^{1}$

THE ROLE OF PARENTAL GUIDANCE ON VOCABULARY ACHIEVEMENT IN AN INDONESIAN EFL ELEMENTARY EDUCATION SETTING

Christian Edison Bani ${ }^{1}$, Sahiruddin ${ }^{2}$, Ika Nurhayani ${ }^{3}$

MENELAAH POTENSI SASTRA PARIWISATA DI TELAGA SARANGAN

Ardi Wina Saputra ${ }^{1}$, Rustiati ${ }^{2}$

MAKNA KULTURAL DALAM LEKSIKON PERHIASAN PENGANTIN SUNDA PRIANGAN (KAJIAN ETNOLINGUISTIK)

Elda Mnemonica Rosadi ${ }^{1}$, Retty Isnendes ${ }^{2}$, Mahmud Fasya ${ }^{3}$

133

THE ENVIRONMENTAL ASPECTS OF ALEXANDRE DUMAS'

THE COUNT OF MONTE CRISTO

Gusti Ayu Made Suarniti ${ }^{1}$ 


\title{
MENELAAH POTENSI SASTRA PARIWISATA DI TELAGA SARANGAN
}

\author{
Ardi Wina Saputra', Rustiati ${ }^{2}$ \\ ${ }^{1}$ Universitas Katolik Widya Mandala, Indonesia, ardiwina.saputra@ukwms.ac.id \\ ${ }^{2}$ Universitas Katolik Widya Mandala
}

\begin{abstract}
ABSTRAK
Penelitian ini bertujuan untuk menggali potensi sastra pariwisata di Telaga Sarangan, Kabupaten Magetan, Jawa Timur. Metode penelitianya menggunakan metode deskriptif kualitatif yang mereduksi alur pikir studi sastra pariwisata dari Yosep Yapi Taum. Sumber data dalam penelitian ini adalah cerita rakyat Telaga Sarangan yang diperoleh melalui transkripsi wawancara sesepuh sekaligus budayawan di Sarangan, dan juga hasil observasi terhadap kondisi fisik Telaga Sarangan. Hasil penelitian ini adalah optimalisasi potensi pengembangan wahana wisata Telaga Sarangan berdasarkan potensi sastra yang telah mengakar di dalamnya. Optimalisasi tersebut dapat ditinjau dari segi lokasi, kuliner, dan wahana wisata lain yang dapat dijadikan rujukan pengembangan berdasarkan cerita rakyat Telaga Sarangan. Optimalisasi dari segi lokasi adalah menciptakan titik-titik penanda memori terjadinya Telaga Sarangan. Dalam bidang kuliner adalah menciptakan wisata kuliner yang khas sesuai dengan cerita di Telaga Sarangan. Dalam bidang wahana adalah menciptakan wisata edukasi terkait dengan asal usul Telaga Sarangan.
\end{abstract}

Kata kunci: sastra, pariwisata, Telaga Sarangan

\begin{abstract}
This study aims to explore the potential of tourism literature in Sarangan Lake, Magetan Regency, East Java. The research method uses a qualitative descriptive method that reduces the flow of thought in the study of tourism literature from Yosep Yapi Taum. The source of data in this study is the folklore of Sarangan Lake which was obtained through transcription of interviews with elders as well as cultural observers in Sarangan, and also the results of observations on the physical condition of Sarangan Lake. The result of this research is the optimization of the potential for the development of the Sarangan Lake tourism vehicle based on the literary potential that has been rooted in it. This optimization can be viewed in terms of location, culinary, and other tourist vehicles that can be used as a reference for development based on the folklore of Telaga Sarangan. Optimization in terms of location is to create memory marker points for Sarangan
\end{abstract}


Lake. In the culinary field, it is to create a unique culinary tour according to the story in Sarangan Lake. In the field of rides, it is creating educational tours related to the origin of Sarangan Lake.

Keywords: literature, tourism, Sarangan Lake

\section{PENDAHULUAN}

Pandemi corona model baru (covid-19), membuat segala sektor industri lumpuh. Salah satu sektor industri yang sangat terdampak adalah sektor pariwisata. Diperlukan inovasi dan kolaborasi lintas disiplin keilmuan untuk mengangkat kembali potensi industri pariwisata. Kolaborasi yang dapat dilakukan adalah dengan memadukan ilmu sastra dengan industri pariwisata. Kolaborasi tersebut bernama sastra pariwisata.

Sektor pariwisata yang dapat dikolaborasikan dengan sastra dikhususkan pada sektor pariwisata yang memiliki rekam jejak historis khususnya dalam hal kesusastraan. Salah satu indikatornya adalah keterkaitan sektor tersebut dengan legenda masyarakat setempat sehingga tetap dekat dengan kearifan lokal yang dimiliki oleh sebuah wahana wisata. Sastra sangat dekat dengan kondisi masyarakat setempat (Amrullah dan Imayah, 2019). Potensi wahana wisata yang memiliki rekam jejak historis dari segi penceritaan, dapat digali secara maksimal dari segi sastra sehingga semakin menambah nilai guna sebuah wahana wisata. Nilai guna inilah yang dijadikan sebagai solusi untuk menangani merosotnya industri pariwisata di era pandemi.

Industri pariwisata di Jawa Timur yang memiliki rekam jejak historis dari segi kesusastraan sekaligus terdampak pandemi corona baru adalah industri pariwisata yang berada di wilayah eks-Karesidenan Madiun. Secara formal, nama karesidenan untuk penyebutan suatu wilayah memang sudah tidak digunakan lagi pasca tahun 1950, sehingga disebut eks karesidenan. Meskipun demikian secara informal, penyebutan wilayah karesidenan ditandai dengan kesamaan plat nomor kendaraan. Wilayah eks karesidenan Madiun meliputi Kota Madiun, Kabupaten Madiun, Kabupaten Magetan, Kabupaten Ngawi, Kabupaten Pacitan, dan Kabupaten Ponorogo. Enam wilayah ini memiliki kedekatan secara geografis dan memiliki kultur yang tidak jauh berbeda satu dengan yang lain. Secara kultural, enam wilayah ini memiliki destinasi wisata sastra yang memiliki kedekatan dengan cerita rakyat penduduk setempat.

Berdasarkan wilayah peneliti, maka peneliti memilih industri pariwisata di Kabupaten Madiun yaitu Telaga Sarangan. Sebelum corona, industri pariwisata lokasi ini dapat memberikan keuntungan maksimal bagi warga sekitar akibat ramainya pengunjung yang datang. Namun saat pandemi, nilai guna wahana ini mengalami kemerosotan yang cukup drastis. Secara historis, lokasi wisata Telaga Sarangan sangat dekat dengan kultur masyarakat di sekitarnya. Lokasi ini memiliki rekam jejak historis kesusastraan yang cukup baik yaitu keberadaan cerita rakyat Telaga Sarangan. 
Sayangnya potensi ini tidak lagi digali secara optimal dan dianggap kuno apalagi mistis sehingga tidak ramah anak. Hal ini diperparah dengan kemajuan teknologi informasi dan komunikasi yang menyebabkan gelombang tsunami informasi Saputra (2019). Tsunami informasi membuat cerita rakyat semakin pudar dan tidak dijamah oleh generasi muda. Penelitian ini perlu dilakukan untuk membuktikan penerapan dari teori sastra pariwisata pada destinasi wisata di Telaga Sarangan. Tujuan utama dalam penelitian ini yaitu menemukan potensi sastra pariwisata di Telaga Sarangan.

\section{METODE}

Metode penelitian ini adalah penelitian kualitatif. Proses penelitian ini menggunakan proses alur studi destinasi wisata sastra oleh Yosep Yapi Taum. Pada dasarnya ada empat tahapan besar yang dilakukan untuk menerapkan teori sastra pariwisata.

Tahap pertama, melakukan pemetaan destinasi pariwisata nasional. Tahap ini dilakukan untuk menentukan destinasi wisata, target pasar, dan batasan destinasi wisata sastra dengan destinasi wisata lain.

Tahap kedua, menganalisis daya saing destinasi wisata sastra. Tahapan ini dilakukan dengan memperhatikan 3 hal yaitu (1) kondisi dan permasalahan pengembangan destinasi pariwisata, (2) tren dan dinamika pasar, dan (3) peluang dan prospek pengembangan destinasi. Tahap ini juga dilakukan dengan cara melakukan analisis lingkungan baik secara internal maupun eksternal.

Tahap ketiga, membentuk visi misi pengembangan destinasi wisata sastra. Apabila destinasi wisata sastra sudah memiliki visi misi sebelumnya, maka keberadaan ilmu sastra dapat digunakan untuk memperkaya, melengkapi, atau memodifikasi visi misi yang ada sehingga semakin sempurna visi misi destinasi wisata sastra yang dituju.

Tahap keempat, merencanakan program pengembangan destinasi wisata sastra. Tahap terakhir ini dapat dilakukan untuk menghasilkan produk yang atraktif, amenitas (menyenangkan), dan mudah dijangkau. Selain itu, tahap ini juga bertujuan untuk mengembangkan infrastruktur, sumber daya manusia, kelembagaan, investasi, dan pemasaran. 


\section{ALUR PIKIR STUDI}

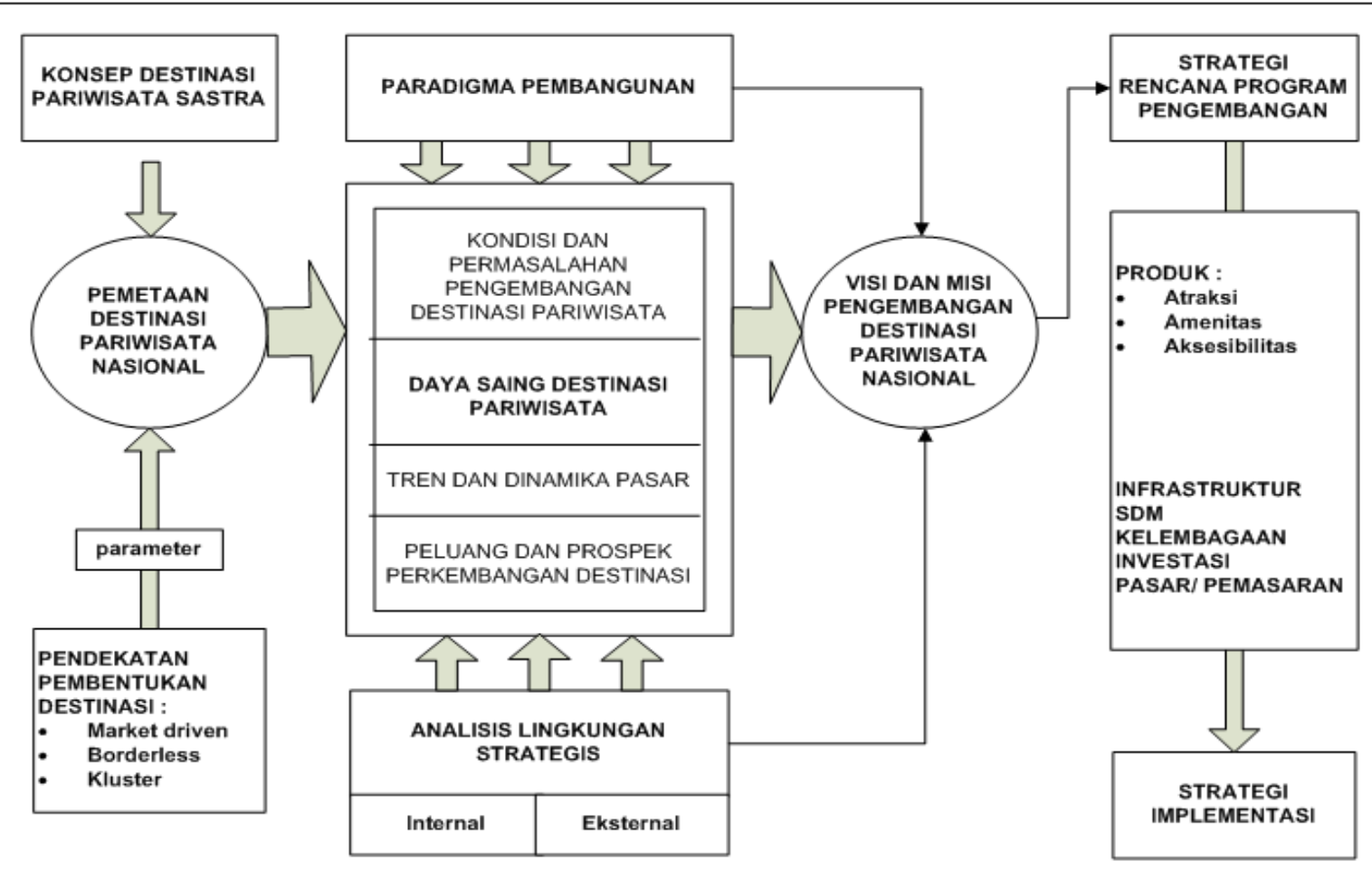

\section{Gambar Alur Pikir Studi Sastra Pariwisata}

Berdasarkan empat tahap tersebut, dalam penelitian ini peneliti melakukan tahap 1 dan 2. Hal ini karena tahap 1 dan 2 sesuai dengan ranah peneliti, sedangkan tahap 3 dan 4 dijadikan rekomendasi pada pihak yang memiliki kewenangan untuk membuat kebijakan dalam hal pariwisata.

Meskipun demikian, peneliti mengoptimalkan dua tahap penelitian dan memperinci tahap kedua untuk menemukan potensi sastra pariwisata pada objek yang diteliti. Potensi sastra pariwisata dapat ditemukan melalui tahap 2 dengan menganalisis daya saing wilayah sastra secara internal dan eksternal. Analisis internal dilakukan dengan menemukan potensi sastra dalam destinasi wisata tersebut, sedangkan analisis eksternal dilakukan dengan cara menemukan potensi wahana wisata berdasarkan sumber sastra yang ditemukan dalam analisis internal. 


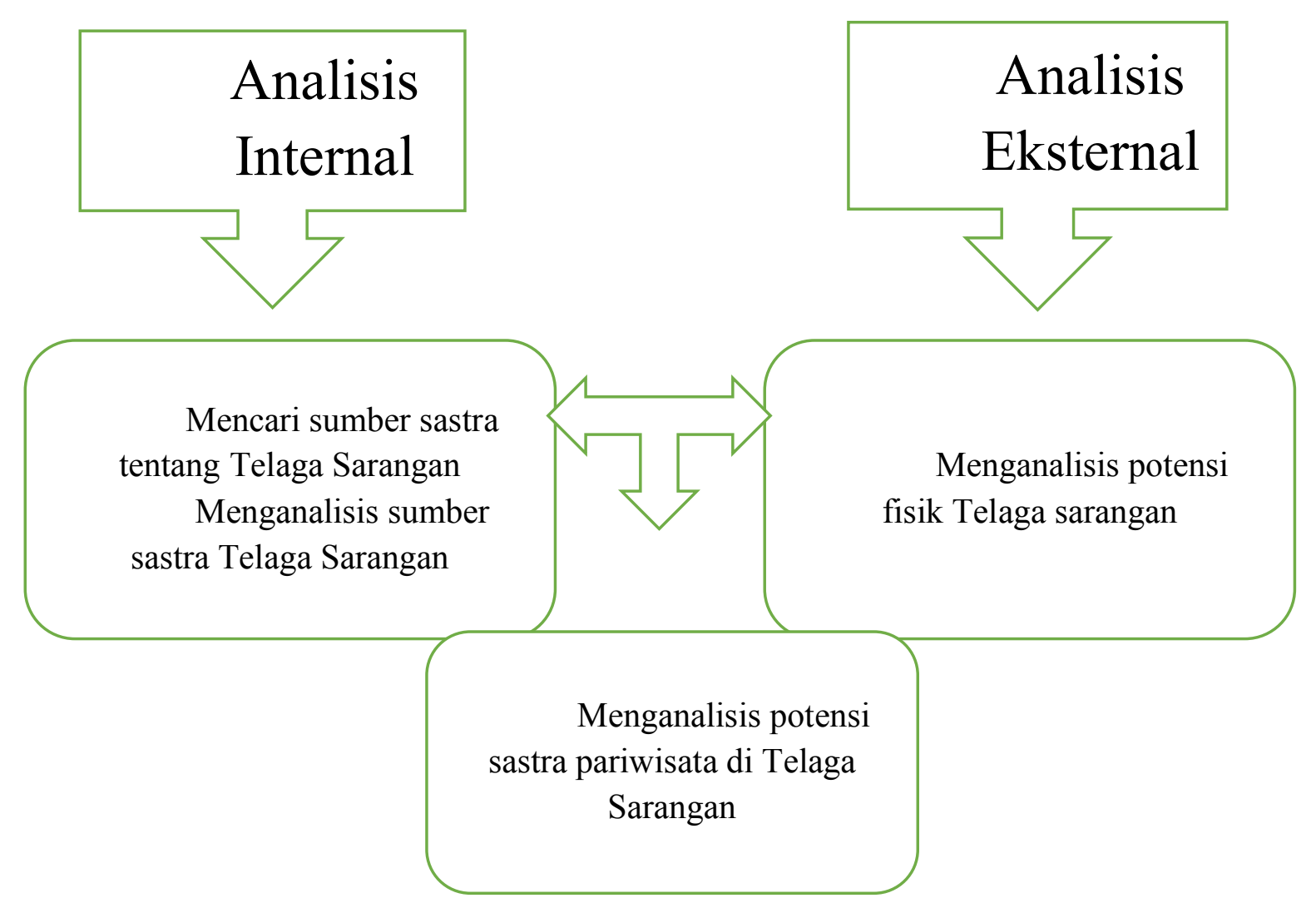

Data dalam penelitian ini berupa sumber sastra yang berkaitan dengan destinasi wisata Telaga Sarangan. Selain itu data juga berupa tuturan cerita rakyat masyarakat setempat yang berada di sekitar wilayah Telaga Sarangan. Teknik pengambilan data berupa studi pustaka, observasi, dan wawancara. Instrumen dalam penelitian ini adalah literatur mengenai Sastra Pariwisata, lembar observasi, dan lembar wawancara. Lokasi penelitian berada di destinasi wisata Jawa Timur, khususnya di Kabupaten Madiun yaitu Wahana Wisata Telaga Sarangan.

\section{HASIL DAN PEMBAHASAN}

\section{Sastra Pariwisata}

Kehadiran studi mengenai sastra pariwisata tentu tidak dapat dilepaskan dari sastra perjalanan. Brown (2020) mengatakan bahwa sastra perjalanan merupakan teks teks sastra yang menceritakan perjalanan seseorang dari satu tempat ke tempat lain.

Dua tahun setelah itu ada kajian mengenai sastra perjalanan berdasarkan karyakarya Mark Twain. Kajian ini menghasilkan temuan bahwa karya Mark Twain diminati oleh dua jenis pembaca, yaitu pembaca yang merupakan wisatawan dan pembaca yang tidak punya kesempatan berwisata. Pembaca yang merupakan wisatawan menggunakan buku Mark Twain sebagai panduan agar tidak mengalami keterkejutan budaya ketika sampai di lokasi tujuan. Di sisi lain, pembaca yang bukan wisatawan memperoleh 
rekreasi imajinatif ketika ingin berkunjung ke suatu wilayah dan tidak kesampaian (Melton, 2002:1).

Empat tahun berikutnya, Waston (2006) secara serius mengerjakan sastra pariwisata melalui penelitiannya mengenai penelitianya tentang pembacaan tempattempat wisata sastra di Inggris . Pada tahun 2007 diselenggarakan konferensi "Literary Tourism and Nineteenth Century Culture" oleh The Institute for English Study di London. Hasil dari konferensi ini berupa 18 artikel mengenai pariwisata sastra yang dikurasi dan dieditori oleh Nicola J. Waston (Putra, 2020).

Satu dekade kemudian sastra pariwisata terus dikembangkan. Dua penulis teori sastra dari Portugis yaitu Rita Baleiro dan Silvia Quintero membuat buku konsep kunci studi sastra dan pariwisata. Dalam buku tersebut mereka mengungkapkan 15 produk pariwisata sastra yaitu (1) kunjungan rumah penulis, (2) kunjungan lokasi yang ada dalam teks sastra, (3) perjalanan sastra, (4) penjelajahan pub (kafe) sastra, (5) festival sastra, (6) kunjungan perpustakaan, (7) kunjungan pameran buku, (8) kunjungan ke taman sastra, (9) tinggal di hotel sastra, (10) tinggal di perpustakaan hotel sastra, (11) kunjungan ke kota/ desa sastra, (12) berpartisipasi dalam kompetisi sastra, (13) berpartisipasi dalam makan malam sastra, (14) berpartisipasi dalam sesi pengajaran dan pembacaan sastra, dan (15) pementasan/pertunjukan sastra (Baleiro, 2018: 38-40). Lima belas produk wisata sastra tersebut kemudian dijadikan bahan penelitian oleh para peneliti sastra termasuk di Indonesia.

Pada tahun 2019 istilah sastra pariwisata mulai masuk ke Indonesia. Putra (2019: 165) mengatakan bahwa sastra pariwisata memiliki 4 cakupan yaitu (1) kajian tematik kepariwisataan dalam karya sastra, (2) aktivitas sastra, (3) kegiatan wisata sastra, dan (4) ekranisasi sastra. Pengembangan tentang penelitian pariwisata sastra mulai bermunculan, salah satunya adalah Pengembangan Wisata Sastra Siti Nurbaya (Ferdinal, Donny dan Gido, 2019:1). Respons kemunculan istilah sastra pariwisata kemudian disambut oleh Himpunan Sarjana Kesusastraan Indonesia. Pada tahun 2020, dimotori oleh Prof. Novi Anoegrajekti dkk, HISKI meluncurkan buku Sastra Pariwisata pada tahun 2020. Buku ini memuat 27 penelitian yang berkaitan dengan Sastra Pariwisata. Penelitian berjudul Pemberdayaan Cerita Rakyat Untuk Pengembangan Destinasi Wisata Yang Berbasis Kekayaan Budaya Indonesia (Sunarti, 2020) dan Destinasi Wisata Sastra Sebagai Bidang Kajian: Beberapa Prinsip dan Prospek (Taum, 2020) menjadi landasan mutakhir penelitian terdahulu dalam proposal penelitian ini. 


\section{STATE OF THE ART SASTRA PARIWISATA}

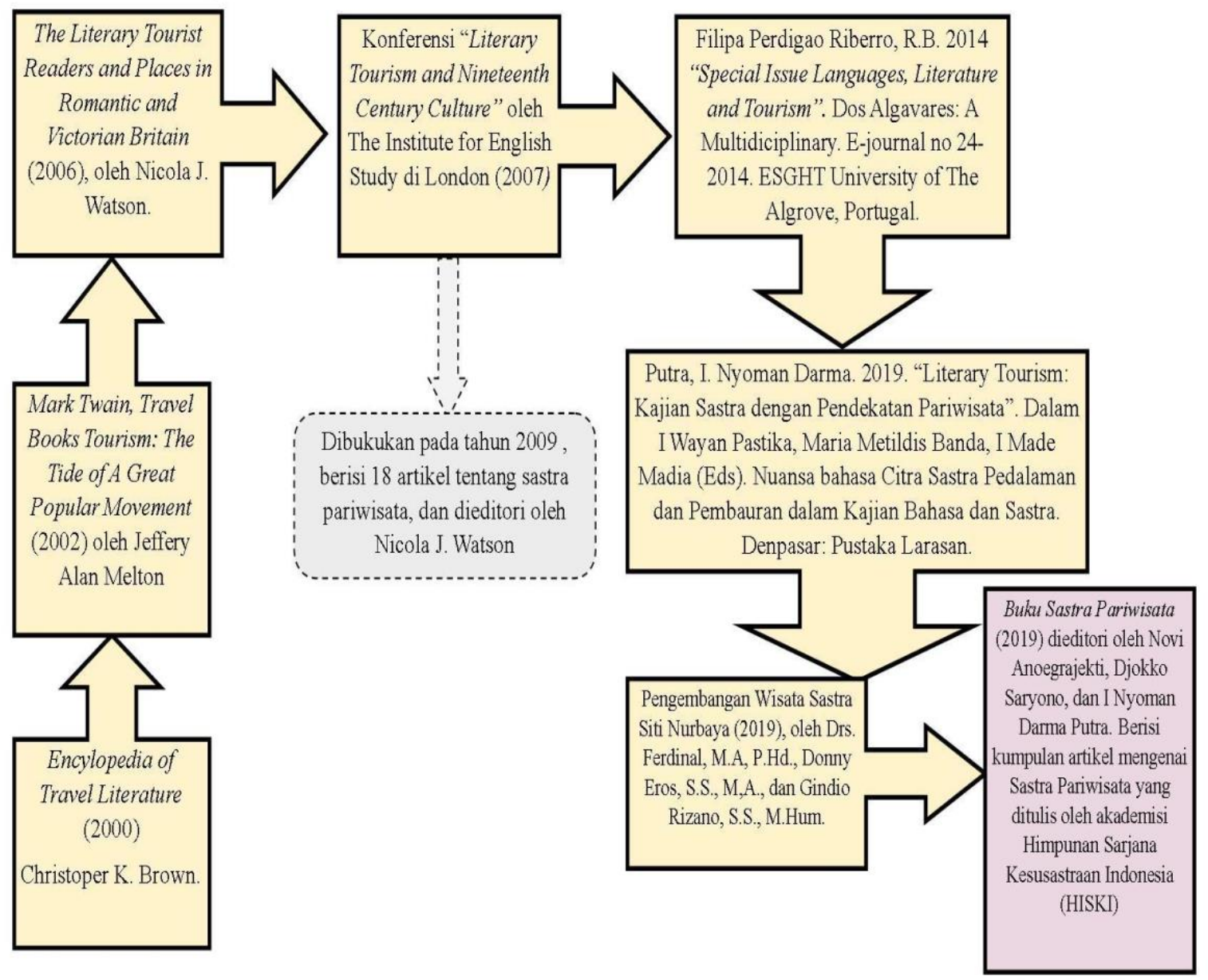

\section{Cerita Telaga Sarangan}

Cerita rakyat di Telaga Sarangan merupakan salah satu wujud sastra lisan yang keberadaanya diturunkan secara turun temurun. Sebagai sastra lisan, tentu pengarang dari cerita ini adalah anonim. Untuk mendapatkan cerita rakyat yang valid mengenai Telaga Sarangan, maka peneliti mengambil data transkrip wawancara terhadap sesepuh sekaligus salah satu orang berpengaruh di Telaga Sarangan. Orang tersebut adalah Mbah Dimun Atmo Sentono yang pada tahun 1991 berusia 80 tahun.

Transkrip wawancara ini ditemukan peneliti berdasarkan studi pustaka terhadap penelitian terdahulu mengenai cerita rakyat, khususnya Telaga Sarangan di Perpustakaan Universitas Katolik Widya Mandala Surabaya Kampus Madiun. Sebagai bagian dari civitas akademika, maka peneliti menindaklanjuti penelitian sebelumnya yang berusaha untuk menggali informasi tentang cerita Rakyat Telaga Sarangan. 
Transkrip wawancara ini valid karena melalui proses validitas yang dilakukan oleh dua senior peneliti yaitu Bapak Suripan Sadi Hutomo, M.Hum., dan Bapak Dr. Herman J.Waluyo. Keduanya merupakan tokoh dalam bidang penelitian sastra Indonesia yang pernah berkarya di kampus peneliti. Transkrip wawancara semula berbahasa Jawa Halus, kemudian ditransliterasikan ke dalam bahasa Indonesia sehingga dapat dimengerti artinya. Berdasarkan hasil dari transliterasi tersebut, dapat diceritakan kembali tentang cerita rakyat Telaga Sarangan.

Cerita tentang Telaga Sarangan dimulai dari migrasi yang dilakukan oleh sepasang pasutri dari Jawa Tengah ke lereng timur Gunung Lawu. Nama pasutri itu adalah Kyai Pasir dan Nyai Pasir. Ketika dalam perjalanan menuju Gunung Lawu, mereka bertemu dengan anak laki-laki bernama Djoko Lelung dan mengangkat anak itu sebagai anak angkat. Mereka melanjutkan perjalanan lagi hingga sampailah mereka di utara Sarangan, tepatnya di hutan Saranggonggang. Di tempat itu mereka menemukan rumah sederhana beratap jerami yang kemudian mereka tinggali. Di situ, mereka juga mulai menanam palawija untuk memenuhi kebutuhan sehari-hari. Mereka juga menemukan sumur dan sumber air sehingga tepatlah ladang yang kosong itu untuk dijadikan sebagai tempat tinggal mereka.

Suatu ketika, saat Djoko Lelung sedang pergi, Nyai Pasir berencana mengirimkan makanan pada suaminya yang sedang bekerja di sawah. Saat sedang berencana menyiapkan makanan, tiba-tiba Nyai Pasir melihat ada telur di semak-semak. Ukurannya besar sekali. Ia lalu mengolah telur agar dapat dihidangkan pada suaminya, Kyai Pasir.

Setelah telur itu disajikan pada Kyai Pasir, ternyata tubuh si Kakek terasa sangat panas. Kyai Pasir lalu mandi. Setelah mandi, tubuhnya terasa semakin panas. Saat Kyai Pasir Mandi, ia meminta istrinya untuk makan juga, dan Nyai Pasir pun juga makan telur yang tersisah. Sekejap kemudian, tubuh Nyai Pasir terasa panas dan gatal. la pun juga ikut mandi, dan semakin disira tubuhnya maka semakin panas rasanya.

Tubuh Kyai dan Nyai Pasir semakin lama semakin membesar dan juga memanjang. Mereka menjelma menjadi naga yang mengibas-ngibaskan ekornya sehingga membentuk telaga. Inilah yang kemudian disebut sebagai Telaga Sarangan. Namun, cerita tidak berhenti sampai di sini.

Djoko Lelung, putra angkat Kyai Pasir dan Nyai Pasir pun suatu ketika pulang. Dia menemui pakaian ayah dan ibunya berada di pinggir danau lengkap dengan tempat makan besi yang tersisah. Dia juga heran pada wilayah yang didatanginya begitu luas, tidak sama dengan wilayah kelahirannya dulu.

Djoko Lelung kebingungan hingga akhirnya dia pasrah dan meminta bantuan pada Yang Maha Kuasa dengan cara bersemedi di bawah pohon besar. Lokasinya di sebelah barat sumber. Dia bermeditasi sepanjang hari, siang dan malam. Hingga suatu malam saat dia bermeditasi, dia mendengarkan suara gaib. Awalnya dia tak mengenali 
empunya suara tapi lambat laun ia menyadari bahwa yang sedang berbicara kepadanya adalah ayahnya yaitu Kyai Pasir.

Kyai Pasir berkata bahwa kedung yang dulu disebut sebagai Telaga Sumber atau Telaga Danau, kini disebut sebagai Telaga Pasir. Hal itu dikarenakan wujud telaga yang berubah menjadi sangat besar disebabkan oleh Kyai Pasir dan Nyai Pasir. Kyai Pasir juga berpesan agar anaknya tidak perlu lagi bertempat tinggal di Saroganggong dan harus mempersiapkan tempat tinggal di sebelah Timur Telaga. Djoko Lelono juga diberi julukan baru saat dewasa yaitu Kyai Jalelung.

Kyai Pasir juga memprediksi bahwa jika suatu saat telaga ini akan ramai dikunjungi orang, hal itu berarti disebabkan oleh kehendak yang maha kuasa. Dia juga berperan bahwa Djoko Lelono harus menjamin keselamatan orang yang nantinya menyusuri napak tilas telaga ini. Meskipun demikian jika ada orang yang sombong, membanggakan kekuatan dan kebesarannya (adigung adiguna) maka tidak diperbolehkan. Haruslah orang yang menerapkan perintah Gusti Allah, menjalankan kebenaran hidup di dunia, menerima apa yang diberikan Gusti Allah.

Selanjutnya, Kyai Jalelung berpesan bahwa dia meletakkan satu lagi telor yang hampir menetas di sebelah utara, di bawah semak-semak. Djoko Lelono diminta ke sana sekitar sepekan lagi agar telur menetas terlebih dahulu. Nantinya apabila telur itu menetas maka akan dinamakan Djoko Baru Klinting.

Nanti jika telur itu sudah menetas entah berwujud apa, bisa jadi hewan, bisa jadi manusia, atau bisa jadi apa saja, tetap akuilah sebagai saudara laki-laki Djoko Lelung. Hal itu karena kondisi telur itu sama seperti Djoko Lelung yang dulu juga ditemukan oleh Kyai Pasir. Kemudian, apabila telur sudah menetas dan dinamai Djoko Baru Klinting, maka tugasnya adalah menempati wilayah itu. Namanya adalah Telaga Ngebel di daerah Ponorogo, dan suatu saat jodohnya juga ada di Telaga Ngebel.

Setelah itu, Kyai Pasir menceritakan bahwa keadaan telaga menjadi sebesar ini terjadi pada hari Jumat Pon, bulan Ruwah. Oleh sebab itu Kyai Pasir berpesan jika suatu saat nanti di era yang ramai, dia ingin anak keturunanya tetap mempringatinya pada hari Jumat Pon, bulan Ruwah, setahun sekali, menggunakan tata cara yang ada dan bersifat semampunya. Pesan ini ditujukan untuk memperingati ulah Kyai Pasir yang menyebabkan kondisi telaga berubah sedemikian rupa. Di akhir pesannya, Kyai Pasir menegaskan agar Djoko Lelung tidak melupakan pesan-pesannya, sehingga jika suatu saat ada era yang ramai, pesan itu dapat dijadikan sebagai sebuah peringatan untuk anak kecil dan untuk orang dewasa.

\section{Analisis Internal}

Analisis internal dilakukan berdasarkan potensi unsur intrinsik yang terdapat dalam cerita rakyat Telaga Sarangan. Unsur intrinsik tersebut diperoleh berdasarkan pembacaan intensif yang dilakukan oleh peneliti pada transkripsi sastra lisan. Transkripsi tersebut merupakan transkripsi data yang dilakukan melalui wawancara pada Mbah 
Dimun Atmo Sentono. Penelitian ini merupakan penelitian yang meninjau mengenai tempat wisata, sehingga unsur intrinsik yang selaras dengan penelitian ini adalah unsur intrinsik yang berkaitan dengan tempat. Berikut adalah unsur intrinsik yang berkaitan dengan tempat dan pemaknaanya.

"Naliko semanten Eyang Pasir madhepok wonten alas Sarangan ingkang sisih ler, pernahipun saking Sarangan ingkang sak puniko ler, dados sak leripun dusun Sarangan alas ingkang miring ngidhul naminipun Alas Saranggonggang. Wonten mriku yoso griyo setunggal inggih griyo sederhana payone inggih alang-alang, genahipun tiyang jaman kuno, makaten kolowau." (Setiowati, 1994)

Pada kutipan cerita tersebut terdapat keterangan tempat yaitu "Alas Sarangan", "sisi utra", “Dusun Sarangan", "menghadap ke selatan", "Alas Saranggonggang", dan "rumah sederhana". Dari rangkaian penggalan keterangan tempat tersebut dapat disusun sebuah narasi bahwa Eyang Pasir berumah di wilayah Dusun Sarangan sebelah utara, tepatnya adalah Alas Saranggonggang. Alas tersebut menghadap ke selatan ke arah Sarangan, sehingga dapat diprediksi bahwa rumah Eyang Pasir menghadap ke selatan meski terletak di sebelah utara Dusun Sarangan. Rumah tersebut sangat sederhana bahkan digambarkan berpayung "alang-alang" atau beratap jerami. Unsur intrinsik berikutnya yang berkaitan dengan tempat adalah kutipan berikut.

"Ing ngriku gancaring carios mekaten, Eyang Pasir ngendiko kalian ingkang putri "Mbokne aku arep macul marang tegal, arep gebal maneh. Mengko aku ora muleh, aku kirimen wae kira-kira trenceng kurang luweh jam songo sepuluh awan, aku engko kirimen." Ngendikane sing putri, "yaa Pakne". Lan mengko Nyai yen putrane dewe Djoko Lelung takon, ngomong nek aku neng tegal Sumber macul, yen aku ora mulih ngono yaa!" Ngendikanepun Eyang Pasir Kakung." (Setiowati, 1994)

Pada kutipan cerita tersebut terdapat dua keterangan tempat yaitu "macul marang tegal" yang artinya bercocok tanam di ladang, dan "Tegal Sumber". Pemaknaan dari kutipan tersebut adalah pesan dari Eyang Pasir pada istrinya bahwa dia hendak bercocok tanam di ladang bernama ladang Sumber. la juga berpesan agar jika dia belum pulang dan putranya mencarinya, maka disampaikan saja bahwa dia sedang berada di Tegal Sumber. Penggalan cerita berikutnya yang berkaitan dengan keterangan tempat yaitu

"Sak sampunipun dugi pategilan dereng ngantos nyambut damel, sawek mubeng-mubeng wonten oro-oro, celaking grumbul suketan mriku wonten endhok kalih. Endhok kalih meniko wau yen wujudipun inggih endhok pitik nanging gedhe, radi gedhe. Endhok kalih meniko wau engkang setunggal dipun pundhut, engkang setunggal dipun simpen wonten mriku meleh, dipun wuruki 
rasak utawi gegodhongan meleh. Dereng ngantos nyambut damel macul utawi kerjo wonten ing pategilan, Eyang Pasir lajeng endhok meniko dipun masak, nek coro siyen nek ngarani dipun benem, dipun buntel godhong disukani banyu lajeng dipun bakar, dipun bakar wonten latu, damel geni wonten ngriku. Sak sampunipun endhok sampun matheng, endhok dipun belah utawi dipun pecah dados kalih, engkang separo dipun dahar piyambakipun, engkang separo dipun simpen, piyambakipun kagungan penggalih bilih mangke engkang putri badhe rawuh anggenipun ngentun sekul saking griyo mangke rawuh, endhok engkang sampun dipun masak wau, sing separo dipun piyambakipun, sing separo dipun ngengehaken engkang putri, mangke badhe dipun caosaken. Ewa semanten saksampunipun Eyang Pasir dahar endhok separo kala wau, badhanipun kraos panas gathel engkang langkung luar biasa gathelipun utawi panasipun badhan langkung sanget. Lajeng piyambakipun adus wonten bilik utawi sendang engkang wonten sekitaripun pategilanipun piyambak meniko kala wau."(Setiowati, 1994)

Kutipan keterangan tempat yang terdapat dalam penggalan cerita tersebut adalah "dari ladang (perladangan-pategilan)", "ada di rawa-rawa", dan "rerumputan yang tebal". Tempat terebut merujuk pada dua telur yang ditemukan oleh Eyang Pasir. Kedua telur tersebut dimasak dengan cara yang sudah disebutkan yaitu "dibenamkan, dibalut daun, diberi air, kemudian dibakar di perapian. Setelah telur matang, maka dibelah dua, yang seprauh untuk dirinya sendiri, dan yang separuh disimpan untuk dimakan Eyang Putri." Berdasarkan penggalan kutipan tersebut, dapat ditarik sebuah potensi wisata kuliner yaitu telur yang dimasak secara tradisional seperti cara Eyang Pasir memasak telur tersebut. Meskipun dalam cerita, telur inilah yang mengakibatkan Eyang Pasir dan istrinya mengalami gatal-gatal lalu mandi dan semakin panjang lebarlah tubuh mereka. Tubuh mereka yang panjang kemudian berubah menjadi naga sehingga membentuk telaga. Penggalan cerita berikutnya yang berkaitan dengan keterangan tempat yaitu

"Lajeng enjingipun antawisipun kirang langkung samtigang dinten anggenipun ngawontenaken goro-goro ingkang sampun kaaturaken ingkang riyen kala wau, Djoko Lelung ngrumaosi wangsul saking dolan utawi saking kesah wau datheng griyo mboten wonten tiyang, bapak lan biyung mboten wonten. Lajeng piyambakipun sampun ngertos bilih gadah tegal wonten kidulipun desa naminipun Tegal Sumber. Ing ngriku lajeng nuju datheng tegil. Datheng ngriku Djoko Lelung rumaos cemar utawi lingsem, kaget kok lajeng kawontenan bilik mundhak ombo lan benten kalian adat engkang sampun lan malih bapa ibunipun mboten wonten, wontenipun naming pakaian sekalian. Pakaian ibune kalian pakaian keng romo wonten sakpinggiripun sendang. Lajeng bekasbekas daharan sik wutuh sak wadah-wadahipun wonten sak celakipun pinggir kedhung meniko wau. "Saking jibekipun raosipun Djoko Lelung lajeng Djoko 
Lelung mesu budi nyuwun dumatheng ngersanipun Gusti Ingkang Maha Agung nyuwun petunjuk. Lajeng dewekipun semedi utawi tapa brata sak ngandapipun selo wonten ngandapipun kayu ageng. Nek sakniki pernahipun wonten ing saknginggilipun sumber, kulon pulo nek sakniki."(Setiowati, 1994)

Kutipan keterangan tempat yang terdapat dalam penggalan ceria tersebut adalah "datang ke rumah", "selatan desa bernama Tegal Sumber", dan "di samping kolam". Penggalan cerita di atas menceritakan tentang kedatangan Djoko Lelung, anak angkat dari Eyang Pasir dan Nyai Pasir. Dia bingung mencari keberadaan kedua orang tuanya yang tidak ada di rumah. Akhirnya dia memutuskan utuk pergi ke selatan desa yaitu wilayah Ladang Sumber. Di sana dia menemukan pakaian dan sisa tempat makan di samping kolam di wilayah pegunungan. Djoko Lelung tentu heran kolamnya menjadi sangat besar dan luas. Itulah sebabnya dia langsung melakukan pertapaan untuk memohon petunjuk pada ilahi. Lokasi pertapaanya adalah "di bawah pohon besar", kalau sekarang di "barat pulau".

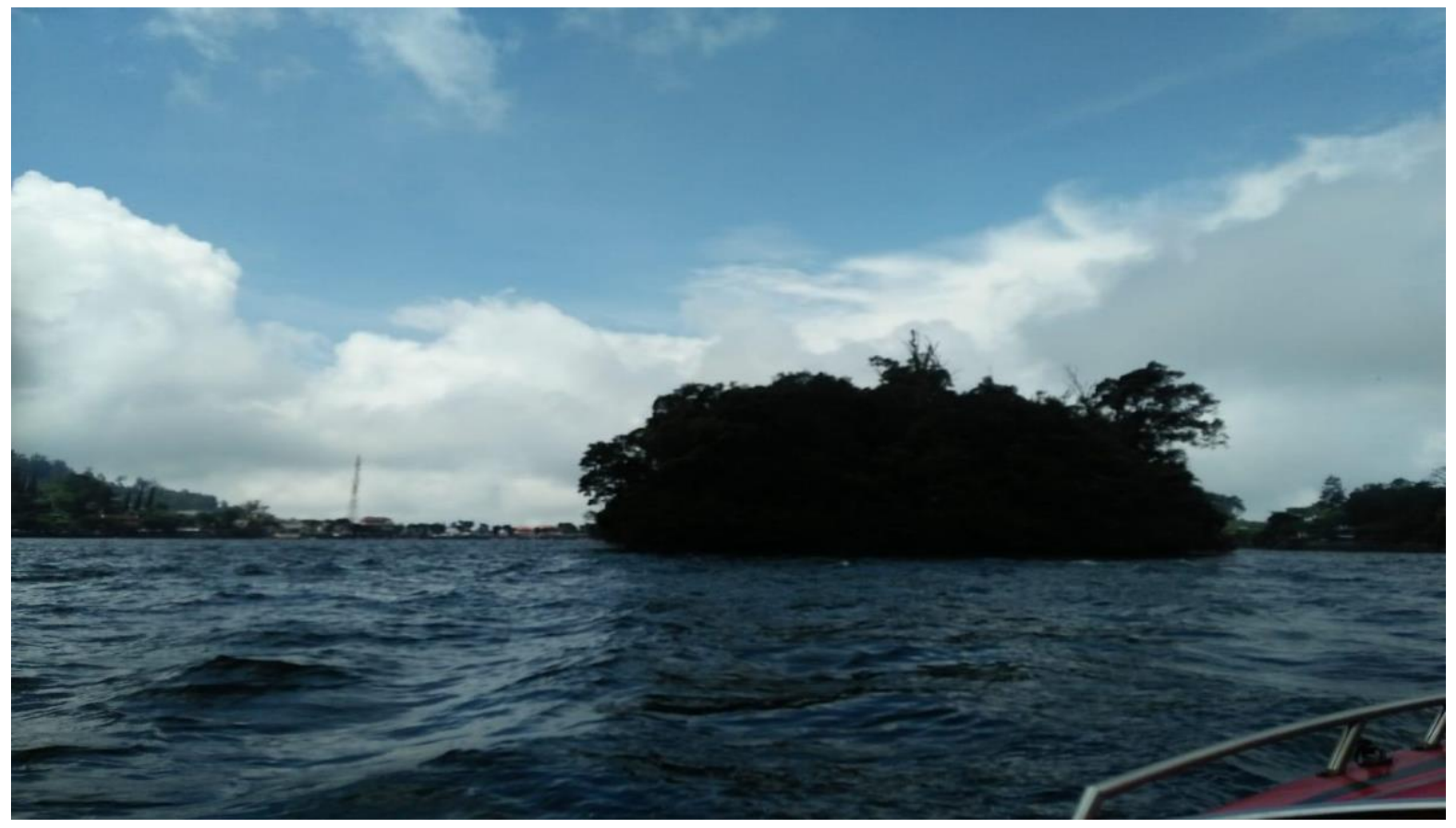

Gambar pulau yang lokasinya berada di tengah Telaga Sarangan

Saat bertapa, dia bertemu dengan saudara ayahnya yang menyiratkan banyak lokasi serta kronologis kejadian penyebab kolam menjadi luas. Berikut kutipannya:

"Oh Ngger anakku Djoko Lelung ojo banget-banget anggonmu ngongso pikiran, pancen wis kinodrate Hyang Windhi dene anggonku momong marang kowe, manggulowentah marang sliramu kira-kira pancen mung cukup semene. Mulo lakone wong tuamu si aku lan ibumu iki sing bakal nutuk ake kowe mulo ora susah kakean sing mbok pikir, tutukno lakone bapakmu ngantek mengko 
tumekan titik ing kodrate Hyang Widhi teko ngendi kowe sing nutokake lakon iki. Sarehne wektu iki dino kowe sing wis ora biso berhadapan karo aku, ora iso ngerti neng aku, nanging aku isih tetep jangkung ngungkul- ngungkuli marang kowe. Senajan kowe ora ngerti nang aku, aku ngerti neng kowe. Mulo ngene yoo Ngger kahanan belik utawa kedung iki biyen jenenge tegal Sumber utawa tegal sendang, iki engko jenengno Tlaga Pasir. Sebab enenge iso koyo ngene iki mung goro-gorone saka bapakmu ya aku iki bapakmu sing jejuluk Kyai Pasir lan Nyai Pasir, ya aku iki. Kedung iso dadi sakmene ambane ya mung gara-gara aku iki, mulo dijenengake Tlaga Pasir lan maneh ya Ngger kowe ora susah madepok ono Saranggonggang kadohan Kowe saiki mulai dino iki tata-tatao madepok ono ing sak wetane Tlaga. Kowe banjur jejuluko mbesuk yen wis dewasa jejuluko Kyai Jalelung. Yen mbesok ono ramene jaman tlaga iki tetep mbesuk ana sing naluri tetep biso rame, biso ngremboko mergo krodate Hyung Widhi pancen kudu kahaman ing daerah kene biso rame sateruse. Sepisan aku mung meling mbesuk yen ono ramene jaman yen ono kawulo sing bakal nitik tilas menyang ing papan tlaga iki kowe kudu kok jangkung keslametane, kowe kudu jangkung ngayomi keslametane marang kawulo kabeh sing pada naluri tiitik tilas marang ing tlaga kene. Nanging pawelingku yen wong sombong adigung adiguno ora ndak parengake, kudu wong apa benere tingkah laku netepi dawuhe Gusti Allah, apa benere urip ing alam donya, nrimo apa paringi Gusti Allah, piwelingku meng koyo ngono kuwi. Sateruse wanti-wanti pawelingku yaa ngger, aku nyeleh endhok siji eneng ngisor grumbul siseh lor eneng oro-oro sacedake tegalan kuwi wis meh netes. Deloken iki wis kethok saka kene looh! endhok kuwi wis meh netes. Nanging kowe ojo pisan-pisan mrono yen durung kurang luwih seminggu bakal keno kok nyatakake. Wingko ujude endhok kuwi nek wis netes wingko jenengno Djoko Baru Klinting. La mengko nek wis ujud mboh ujude apa, ora ketang ujud kewan, ora ketang ujud manungso, ujud apa wae, dakunen dulurmu lanang, kuwi pada karo kowe. Kuwi yo lehku nemu, kowe biyen yo lehku nemu. Dadi dakunen dulurmu lanang. lan maneh nek wis kok jenengake Djoko Baru Klinting, tugase kuwi engko kowe karek nerusake. Tugase kudu manggon ono telaga Ngebel ing daerah Ponorogo lan mbesuk jodone dulurmu yo wis ono Tlaga Ngebel. Sing wajib njaga ono ing tlaga Ngebel ya kuwi lan maneh kuwi engko kudu kok daku sedulurmu lanang. Ora keno pisan-pisan kumpul karo kowe ing Tlaga Sarangan kene. Mengko sak bubare kuwi kudu manggon ono ing Tlaga Ngebel, ning lakune kudu nngetan bener saka kene. (Setiowati, 1994)

Kutipan mengenai keterangan tempat adalah "Tlaga Pasir" dan "Tlaga Ngebel". Dua tempat ini merupakan potensi besar yang dapat diangkat sebagai wahana sstra pariwisata dan terhubung satu dengan yang lain. Berdasarkan cerita yang dituturkan 
dalam sastra lisan, jelas dikatakan bahwa asal muasal Tlaga Pasir adalah bentukan dari tubuh Eyang Pasir dan Nyai Pasir yang berubah menjadi naga. Wejangan itu secara tersurat bahkan dikatakan pada anaknya yaitu Djoko Lelung atau Kyai Jalelung. Selain itu, dalam cerita juga dikatakan bahwa Telaga Ngebel yang terdapat di Ponorogo juga ada kaitanya dengan Telaga Pasir. Keterkaitan tersebut bahkan diibaratkan seperti halnya dua saudara. Di Telaga Ngebel terdapat telur yang kemudian jika menetas apapun wujudnya harus dinamai Djoko Baru Klinting dan harus mendiami tempat itu. Ini sesungguhnya menunjukkan pertalian antara Telaga Sarangan dan Telaga Ngebel, antara Madiun dan Ponorogo. Apabila kedua potensi wisata ini bisa disatukan atas nama sastra maka bukan tidak mungkin terjadi simbiosis mutualisme baik dalam hal pariwisata terlebih dalam hal kultural.

\section{Analisis Eksternal}

Analisis eksternal diperoleh dengan cara menganalisis potensi fisik Telaga Sarangan. Di Telaga Sarangan terdapat dua potensi fisik utama, yaitu potensi fisik alami dan potensi fisik buatan. Potensi fisik alami merupakan potensi fisik yang disebabkan oleh peristiwa alam. Pemandangan dan Telaga adalah dua potensi fisik utama untuk dijadikan sebagai sumber pariwisata di Telaga Sarangan.

Potensi fisik buatan yang terdapat di Telaga Sarangan dibagi menjadi yaitu, (1) pasar tradisional, (2) penjual baju, (3) penginapan, (4) penjual makanan, (5) jasa menunggang kuda, dan (6) jasa speedboat. Keenam potensi fisik buatan ini merupakan enam potensi fisik yang saat ini sudah terdapat di wilayah Telaga Sarangan.

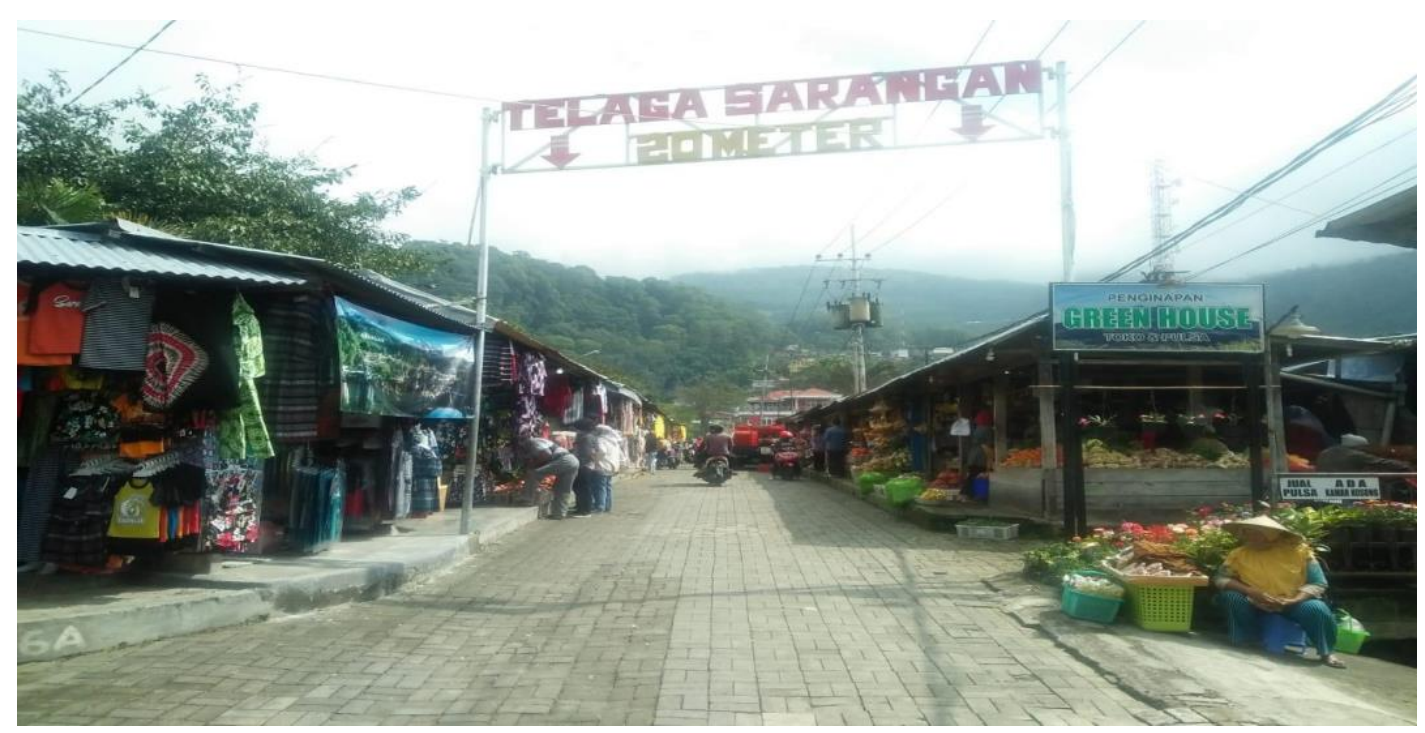




\section{Gambar Pasar Tradisional di Telaga Sarangan}

Pasar tradisional ini menjual beraneka ragam kebutuhan bahan pokok, seperti sembilan bahan pokok atau sembako, sayur, dan buah. Warga sekitar dan wisatawan banyak yang berbelanja di pasar ini. Selain kebutuhan pangan, di pasar juga menjual kebutuhan sandang khususnya baju-baju sehingga tampak bahwa penjual makanan berada di sisi kanan jalan dan penjual baju berada di sisi kiri jalan.

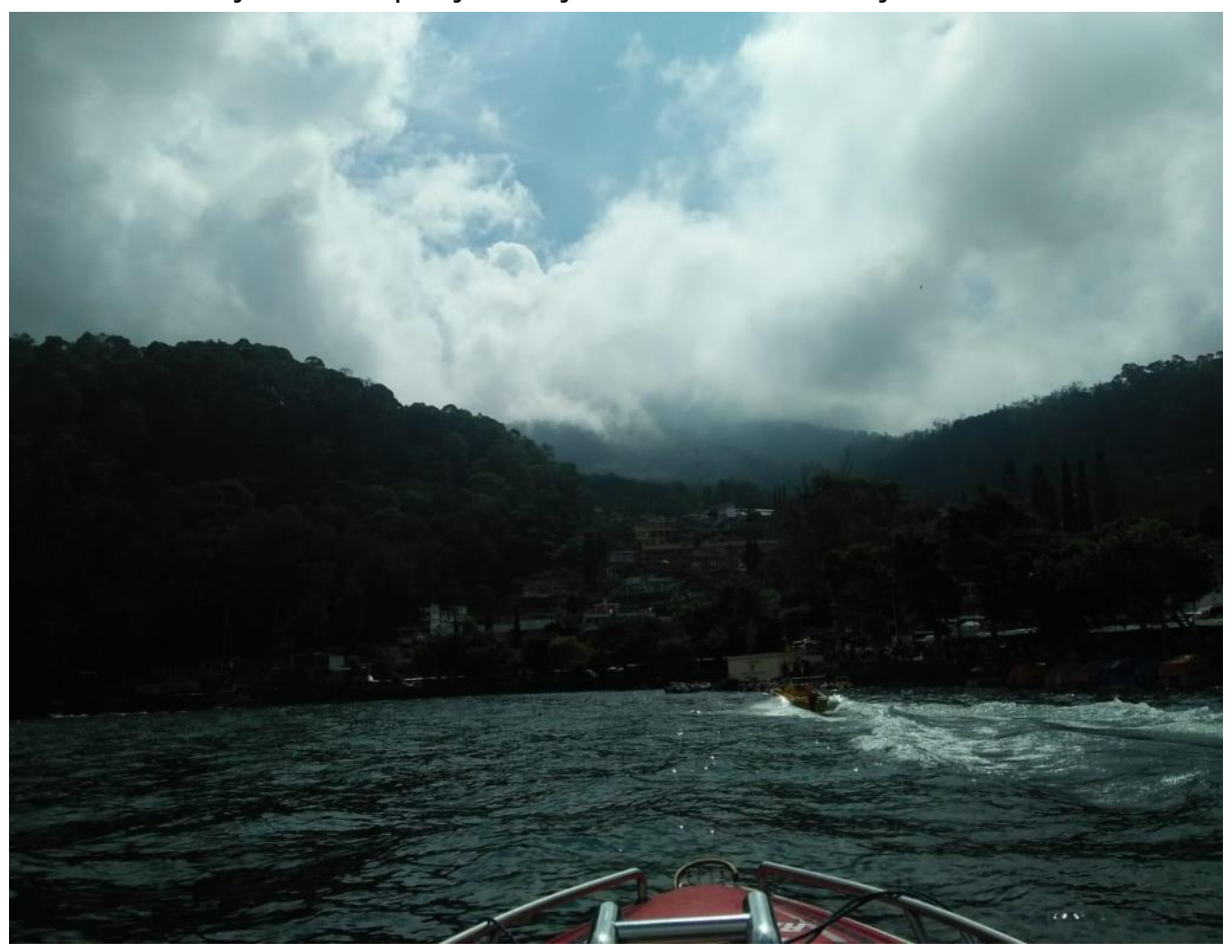

\section{Gambar Pemandangan Penginapan di Telaga Sarangan}

Penginapan di Telaga Sarangan memiliki kelebihan tersendiri yaitu lokasinya yang indah dan juga dingin karena berada di dataran tinggi dan wilayah pegunungan. Dua keunggulan inilah yang seringkali dimanfaatkan baik wisatawan dalam negeri maupun luar negeri sebagai tempat untuk istirahat. 


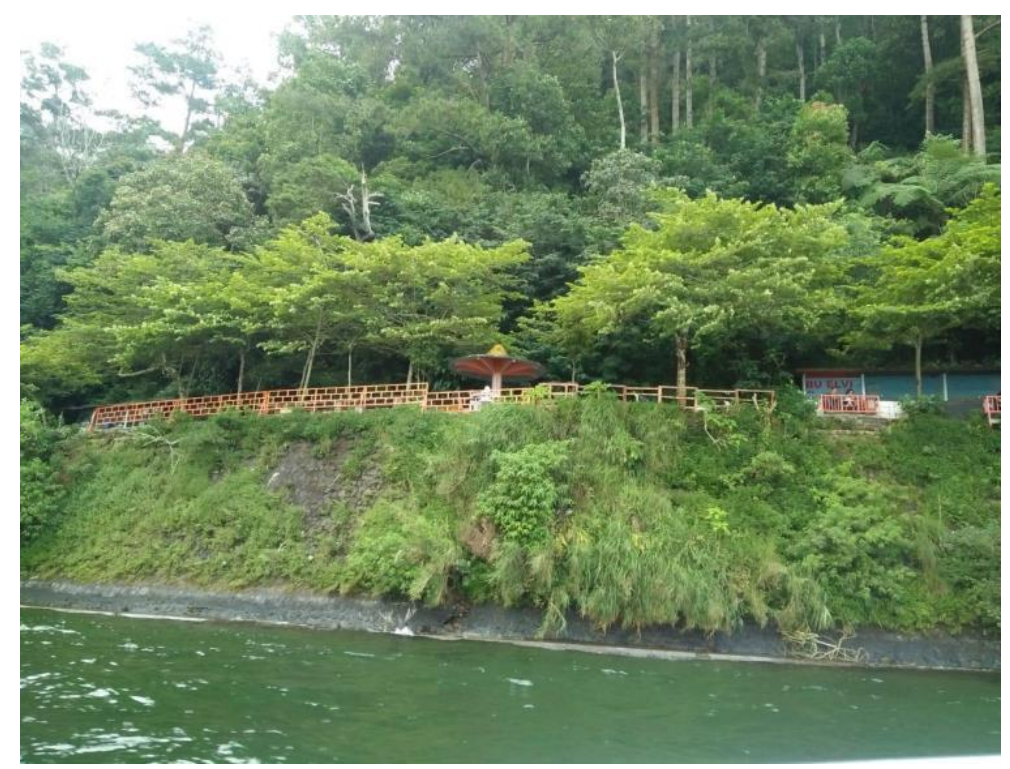

Gambar Wisata Kuliner di Telaga Sarangan

Menu kuliner utama di Telaga Sarangan adalah sate ayam dan sate kelinci. Dua menu ini tampak lebih mendominasi daripada dua menu lainya. Harganya pun standard dan tidak terlalu mahal karena seragam dari ujung penjual satu ke ujung lainya. Harga sate ayam sekitar 12.000 rupiah dan harga sate kelinci sekitar 15.000 rupiah. Menikmati sate sambil melihat pemandangan telaga merupakan salah satu keistimewaan berkuliner di Sarangan ini. Selain sate ada juga mie, bakso, jagung rebus, pecel, nasi jotos, dan jajanan lainnya. Namun sayang tidak ada telur bakar di Telaga Sarangan.

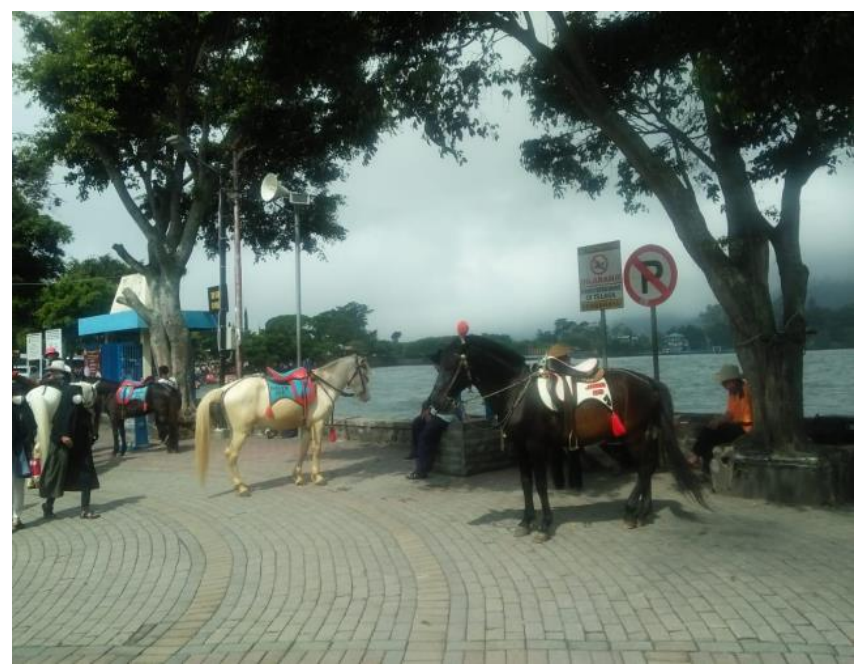




\section{Gambar Jasa Menunggang Kuda dan Speed Boat}

Dua wahana jasa di Wisata Telaga Sarangan yang juga cukup dominan adalah jasa menunggang kuda dan jasa Speed Boat. Jasa menunggang kuda dibanderol dengan tarif 90.000 rupiah dan Speed Boat dengan tarif 60.000 rupiah untuk satu kali putaran, serta 150.000 rupiah untuk tiga kali putaran. Kuda memanglah bentuk kendaraan masa lalu sehingga tetap relevan dengan kondisi sekarang dan terlebih relevan dengan cerita rakyat mengenai Telaga Sarangan.

\section{Potensi Sastra Pariwisata}

Potensi sastra Pariwisata merupakan gabungan dari unsur sastra dan unsur pariwisata. Banyak sekali unsur sastra yang belum dioptimalkan dalam wisata Telaga Sarangan. Kisah tentang Eyang Pasir dan Nyai Pasir sekan hanya terpatri di dua tempat yaitu di bawah tulisan telaga Sarangan dan di monumen Telaga Sarangan.

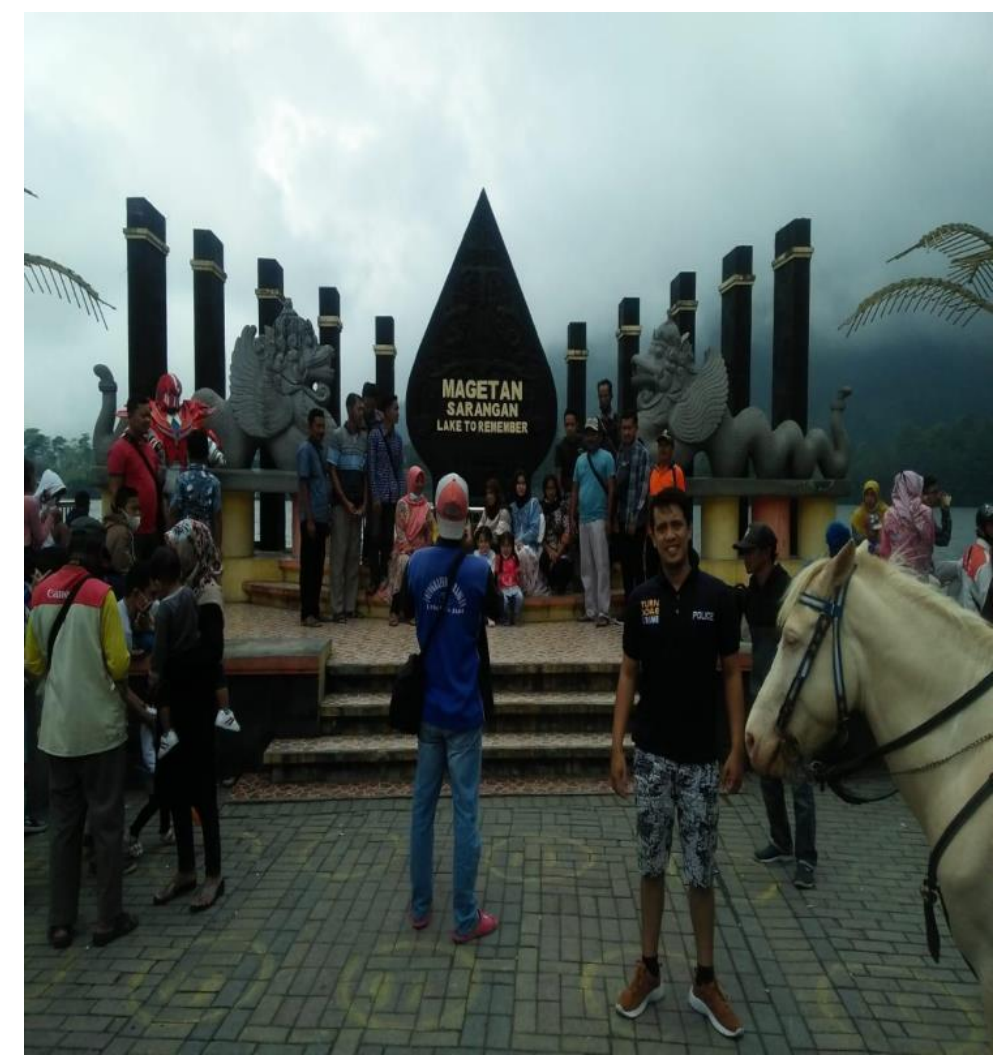

Gambar Monumen Telaga Sarangan

Di monumen tersebut ada tulisan "Lake to Remember". Tulisan tersebut baik tapi alangkah baiknya jika dikaitkan dengan potensi sastranya. Dalam cerita rakyat Telaga Sarangan Kyai Pasir memang pernah berpesan:

"Sateruse rehne kadadean wujud tlaga iso dadi koyo ngene mau dinane Jumat

Pon iki sasine Ruwah, mulo aku meling wanti-wanti marang kowe yen ono 
ramene jaman yen kowe kepingin yaiku naluri utowo tenger wi mbesuk pendak dino Jumat Pon setahun pisan sasine ruwah kok tengerono nganggo keno diarani tata cara manut sak mampune. Idep-idep kowe naluri utowo mrengeti anggonku ngenekake goro-goro sing sakiki koyo mangkene iki. Ojo lali welengku menawa ono ramene jaman mbesuk keno kanggo pengeling-elinge kawulo cilik, kawulo gedhe sakteruse." (Setiowati, 1994)

Peringatan tersebut seharusnya diperingati dan dijadikan sebagai potensi swisata sakral bagi para pengunjung sehingga unsur kulturalnya tetap dapat dirasakan baik oleh turis domestik maupun turis mancanegara .

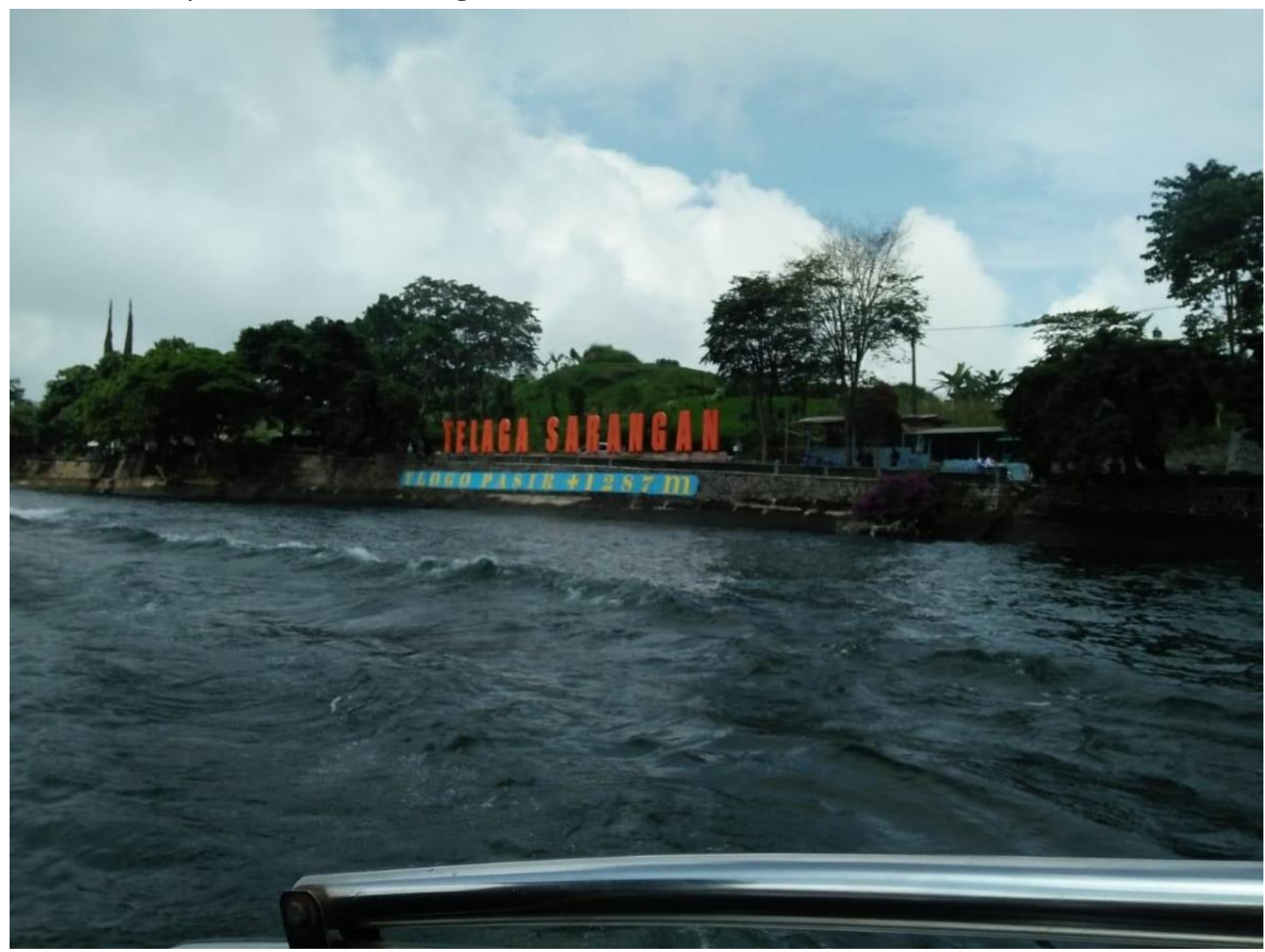

Gambar Tulisan Telaga Pasir di bawah tulisan Telaga Sarangan

Jejak Eyang Pasir yang paling mencolok untuk disaksikan oleh pengunjung hanya tertulis di bawah tulisan Telaga Sarangan. Itu pun dengan tulisan yang lebih kecil dan warna huruf yang samar, tidak sejelas huruf bertuliskan Telaga Sarangan. Di samping tulisan Telaga Pasir terdapat identitas kedalaman telaga sehingga semakin kaburlah informasi mengenai Telaga Pasir karena ada dua informasi penting dalam satu baris tulisan yaitu informasi mengenai Telaga Pasir dan informasi mengenai kedalaman telaga. Bagi wisatawan yang ahistoris dan lebih cenderung rekreatif maka yang teringat hanyalah tulisan kedalamanya saja sedangkan Telaga Pasir akan mudah diabaikan. Oleh sebab itu diperlukan penanda lain yang lebih tegas terkait unsur kultural Telaga Sarangan, terlebih yang berkaitan dengan cerita rakyatnya. 


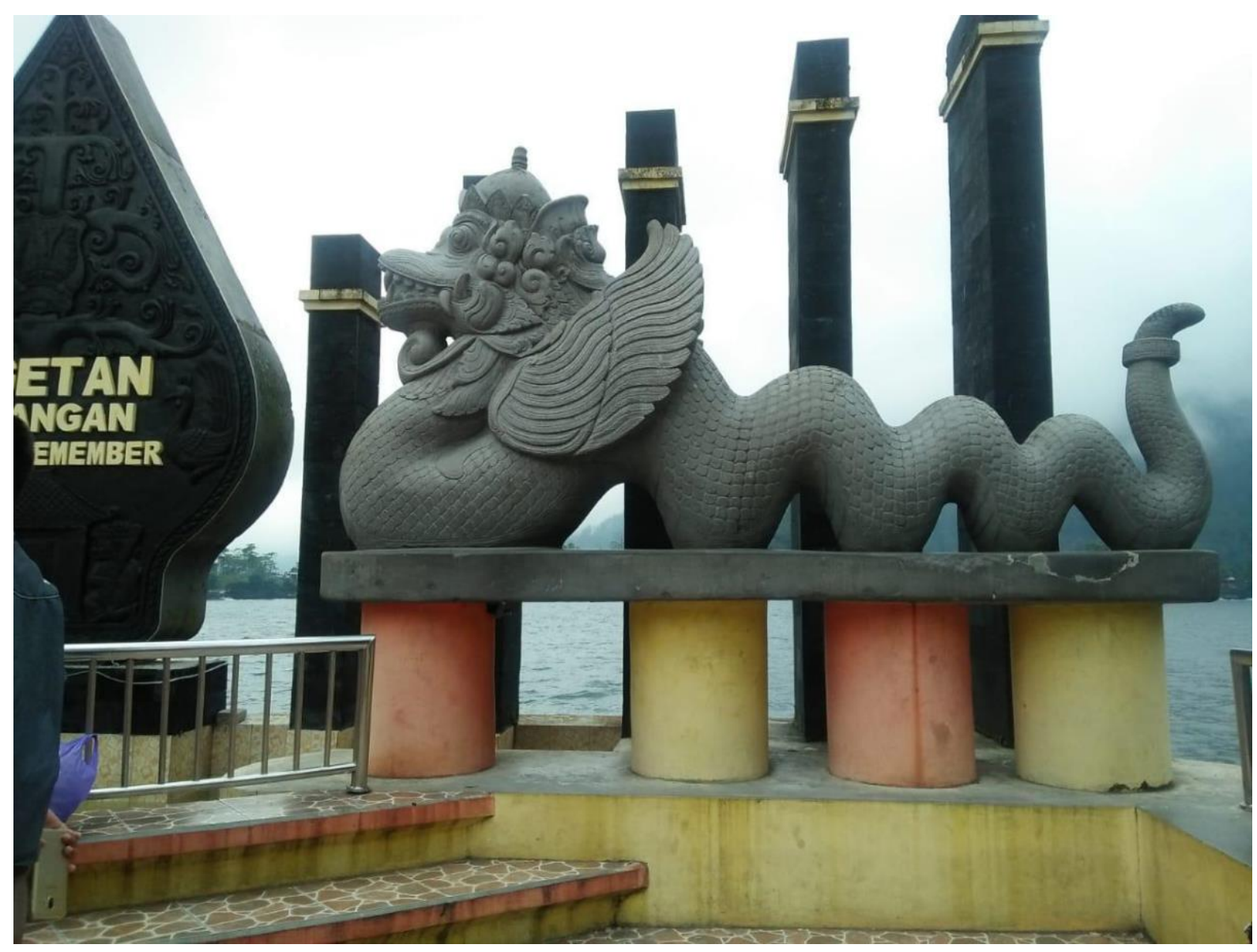

Gambar Naga di Salah Satu Sisi Monumen Telaga Sarangan

Naga di monumen Telaga Sarangan juga merupakan penanda cerita rakyat Telaga Sarangan. Namun sayang belum dimaksimalkan lagi potensinya. Naga hanya berfungsi sebagai hiasan tanpa ada usaha untuk mentransliterasikan atau memberikan keterangan secara tekstual di bawahnya sehingga pengunjung tidak hanya sekedar berfoto tapi juga teredukasi mengenai keberadaan ikon naga di tempat tersebut.

Selain itu, ada potensi wisata lagi yang belum dioptimalkan yaitu telur bakar. Telur ini sangat tersurat dalam cerita dan seharusnya dalam potensi eksternal, ada penjual yang menjual telur bakar ini sebagai penanda budaya.

Bentuk penginapannya juga dapat dijadikan sebagai potensi wisata di Telaga Sarangan. Apabila menyesuaikan dengan cerita, maka bentuk penginapanya seharusnya ada yang didesain beratap jerami dan didesain sederhana tapi bersih. Hal ini pun juga sesuai dengan rumah yang ditinggali oleh Kyai Pasir dan Nyai Pasir. Di tengah kemajuan arsitektur dan desain interior yang sangat inovatif, bukan tidak mungkin bahwa penginapan bermodel rumah Eyang pasir dapat ditata semenarik mungkin sehingga mampu menarik wisatawan. 


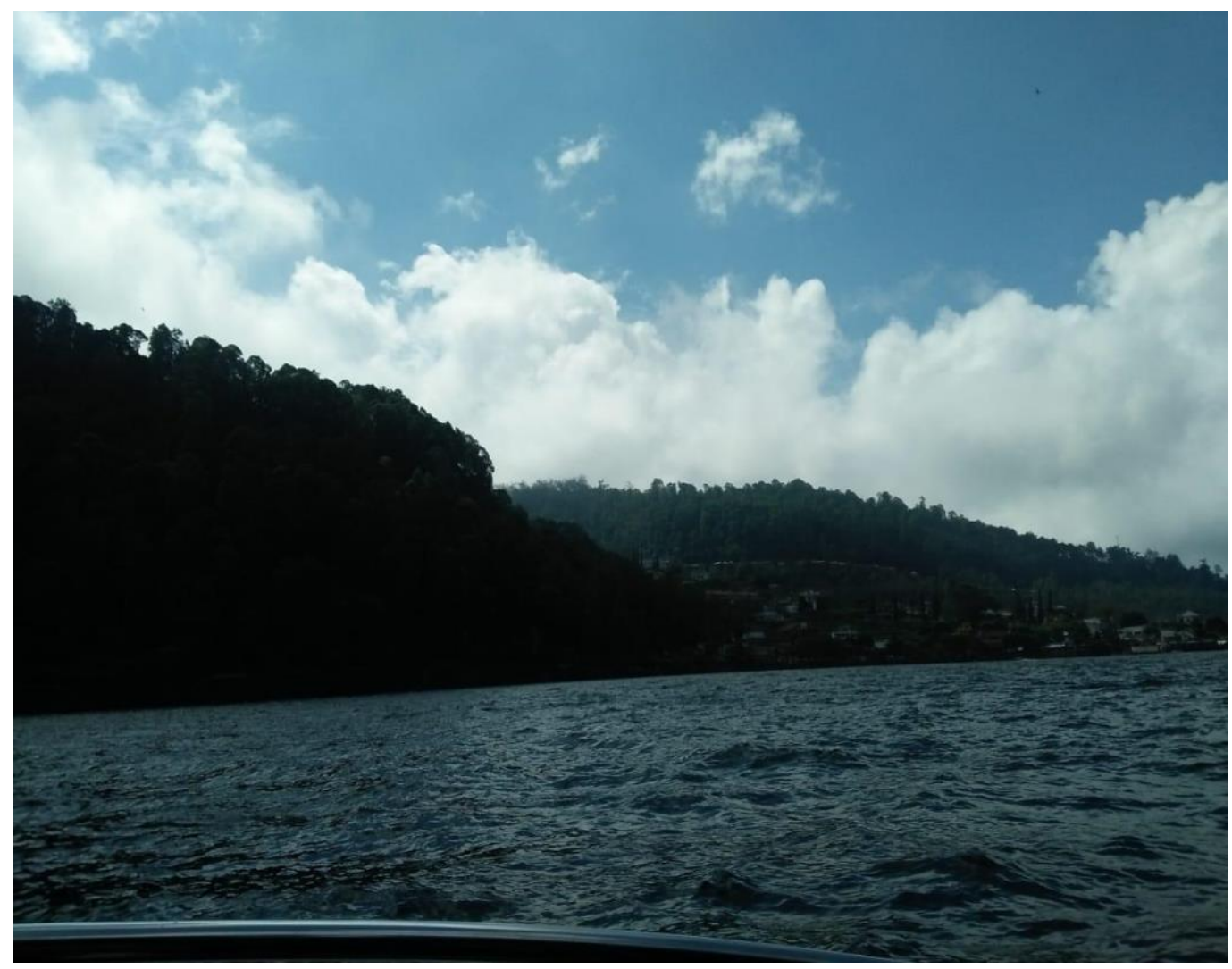

Gambar lokasi peristiwa yang disesuaikan dengan cerita rakyat

Potensi yang terakhir adalah titik-titik lokasi peristiwa. Tempat Kyai Pasir dan Nyai pasir berladang, tempat Kyai pasir menemukan telur, hingga tempat Kyai Jalelung bertapa harusnya direkonstruksi sedemikian rupa atau bahkan dimonumenkan atau dipatungkan sehingga terdapat sebuah rute wisata edukatif yang sesuai dengan jalan cerita Telaga Sarangan ini.

\section{SIMPULAN}

Sastra pariwisata merupakan salah satu cabang ilmu sastra baru yang masuk ke Indonesia. Tepatnya pada tahun 2019, cabang ilmu ini mulai diperkenalkan dan pada tahun 2020 Himpunan Kesusastraan Indonesia mulai membuat rancang bangun serta embrio mengenai sastra pariwisata.

Mengawinkan sastra dengan pariwisata merupakan upaya untuk mengangkat potensi wisata sekaligus mengangkat pula susastra yang menyertai lokasi wahana wisata tersebut. Masih banyak wahana wisata di Indonesia yang dapat dioptimalkan potensinya melalui sastra, salah satunya adalah Telaga Sarangan yang terletak di Kabupaten Magetan, Jawa Timur.

Meneliti sastra pariwisata berarti menggabungkan potensi internal karya sastra dan potensi eksternal karya sastra. Potensi internal ini dapat ditinjau dari unsur intrinsik, terlebih yang berkaitan dengan latar atau tempat, sedangkan potensi eksternal dapat ditinjau dari unsur ekstrinsik yang berkaitan dengan kondisi fisik wahana wisata. 
Berdasarkan hasil penelitian dapat bahwa masih banyak potensi wisata sastra yang dapat dikembangkan di Telaga Sarangan. Apabila pengembang wisata Telaga Sarangan berani mengembangkan wahana wisata ini dengan mengangkat potensi sastranya, maka dapat dipastikan bahwa wahana wisata Telaga Sarangan semakin unik, menarik, dan terlebih mampu mengedukasi wisatawan khususnya dari segi kultural.

\section{DAFTAR PUSTAKA}

Amrullah, I., \& Imayah, I. (2019). Fenomena gincu dalam cerpen Indonesia bertajuk gincu. KLAUSA (Kajian Linguistik, Pembelajaran Bahasa, dan Sastra), 3(01), 1-6.

Brown, C. K. (2000). Encylopedia of travel literature. Santa Barbara: ABC-CLIO.

Ferdinal, Eros. D, \& Rizano. G. (2019). Buku panduan pengembangan wisata sastra Siti Nurbaya. Padang: LPTIK Universitas Andalas.

Filipa P. \& Ribeiro, R. B. (2014) "Special issue languages, literature and tourism". Dos Algraves: A Multidiciplinary. e-Journal no. 24 -2014 ESGHT-University of The Algarve, Portugal.

KEMENPAR. (2016). Laporan akuntabilitas kinerja kementerian pariwisata. Kementerian Pariwisata.

KEMENPAR. (2019). Laporan akuntabilitas kinerja kementerian pariwisata. Kementerian Pariwisata.

Melton, J. A. (2002). Mark Twain, travel books tourism: the tide of a great popular movement. The University of Alabama Press.

Putra, I N.S. (2009). "Literary tourism: kajian sastra dengan pendekatan pariwisata". Dalam I Wayan Pastika, Maria Matildis Banda, I Made Madia (Eds). Nuansa Bahasa Citra Sastra Pedalaman dan Pembaruan dalam Kajian Bahasa dan Sastra. Pustaka Larasan.

Saputra, A. W. (2019). Penyusunan laman menulis berita untuk kegiatan ekstrakurikuler jurnalistik SMA. KLAUSA (Kajian Linguistik, Pembelajaran Bahasa, dan Sastra), 3(2), 89-97.

Setiowati, E. (1994). Cerita rakyat di sekitar telaga Sarangan dan kemungkinan sumbanganya bagi kesusastraan dan pendidikan di Indonesia. Universitas Katolik Widya Mandala Madiun.

Sugiyono. (2011). Metode penelitian pendidikan. Rosda.

Sunarti, S.(2020). "Pemberdayaan cerita rakyat untuk pengembangan destinasi wisata yang berbasis kekayaan budaya Indonesia". Dalam Novi Anoegrajekti, Djoko Saryono, dan I Nyoman Darma Putra. Sastra Pariwisata. Yogyakarta: Kanisius.

Taum, Y.Y. (2020). “Destinasi wisata sastra sebagai bidang kajian: beberapa prinsip dan prospek". Dalam Novi Anoegrajekti, Djoko Saryono, dan I Nyoman Darma Putra. Sastra Pariwisata. Yogyakarta: Kanisius.

Watson, N.J (2006). The literary tourist readers and places in Romantic and Victorian Britain. Basingstoke: Palgrave Macmillan. 
132|DOI: 10.33479/klausa.v5i02.428 